\title{
Louise Bryant and the Russian Revolution
}

\section{Lee A. Farrow}

In 1917, Russia was shaken to its core by revolution and the world would never be the same. The year began with the collapse of Russia's monarchy, the end of a three hundred-year-old dynasty, and ended with the successful takeover of a small group of Marxist revolutionaries called the Bolsheviks. In the year that followed, the new Bolshevik government would withdraw Russia from World War I and establish the foundation for a communist regime that would last for over seven decades and inspire similar revolutions in other countries. As the world monitored these events from afar, there were a few foreign journalists who were on site, witnessing the unfolding of one of the most dramatic and significant events of the twentieth century. Louise Bryant was one of those lucky few.

Louise Bryant was born Anna Louisa Mohan on December 5, 1885, in San Francisco. When she was six, her mother remarried and she became Anna Louisa Bryant, though for most of her life she was known as Louise. Growing up, she lived for several years with her step-grandfather in Nevada, which is what likely led her later to attend the University of Nevada in Reno. At the University of Nevada, Bryant played basketball and was on the staff of several university publications. Subsequently, she attended the University of Oregon at Eugene, where she continued to write. It was also here that Louise exhibited the first signs of the free spirit that lurked within her, developing a slightly scandalous reputation for drinking, smoking, and wearing rouge. She completed a degree in history in early 1909. ${ }^{1}$

After leaving the university, Bryant moved to Portland to find a job as a journalist. She soon began work with a small paper called The Spectator and became involved in local theater. She also met and married a local dentist, Paul Trullinger. As Bryant continued to work for The Spectator and became its society editor in 1913, she also became more political, developing a passion for the suffragist and socialist movements. Soon, she was working to get subscriptions in Oregon for The Masses, a magazine founded in 1911 dedicated to socialist ideals. Among the writers for The Masses was John Reed, a young socialist who was quickly making a name for himself in journalist circles. Bryant read Reed's articles, and

1 Mary V. Dearborn, Queen of Bohemia: The Life of Louise Bryant (Boston: Houghton Mifflin, 1996), 10-18; Virginia Gardner, "Friend and Lover": The Life of Louise Bryant (New York: Horizon, 1982), 19-25. 
finally met him in late 1914 in Portland. Within a month, she left her husband and traveled to New York to be with Reed. Over the next few years, Bryant and Reed lived in New York City and Provincetown, writing and staging plays with friends such as the playwright Eugene O'Neil, and opening a theater. Bryant and Reed married in $1916 .^{2}$

Even before the outbreak of revolution in Russia, Bryant and Reed had been following the events of World War I. They were opposed to war in general and especially to American involvement in the war. In the summer of 1917, both set sail for Russia by way of Stockholm aboard the Danish steamer United States. Over the next months, Bryant and Reed developed their skills in the Russian language as they closely monitored the spectacular events unfolding in St. Petersburg, or, as it was now known, Petrograd. (The latter, less German name, was adopted after the war with Germany began.) They attended meetings that often lasted until four in the morning, and when the revolution began they made their way to the Winter Palace as it was under attack. Armed only with special passes from the Military Revolutionary Committee, Bryant and Reed entered the palace and witnessed the surrender of the palace guards. Over the next weeks, they observed the evolution of the young regime and met many of its most important figures, including Vladimir Lenin, Lev (Leon) Trotsky, Lev Kamenev, and Alexandra Kollontai. Interestingly, though Joseph Stalin would become leader of the Soviet Union a decade later and rewrite history to give himself a central role in the revolution, Bryant does not mention him at all. ${ }^{3}$

The political and social collapse that occurred in early 1917 did not appear out of thin air, of course. For decades, Russia had been experiencing the growing pains that often accompany industrialization and modernization. Over the course of the nineteenth century, Russia's intelligentsia had grown from a small cluster of privileged nobles to a much larger group that included men and women from the nobility as well as the children of priests, bureaucrats, teachers, and lawyers. As time progressed, many of these intellectuals, influenced by the various strains of socialism popular in Western Europe, began to challenge the status quo in Russia, demanding the freedoms and civil rights of their contemporaries elsewhere. Frustrated with the oppressive tsarist regime, some of these became revolutionaries, advocating violence to bring down the system by attacking its heart, the monarchy. In 1881, for example, a group of revolutionaries assassinated Tsar Alexander II, throwing a bomb under his carriage as it traveled through the streets of St. Petersburg. Not surprisingly, the new tsar, his son Alexander III, cracked down on the emerging revolutionary movement, arresting the members of various organizations and imposing restrictions on universities and the press. Alexander III's son and heir, Nicholas II, continued to pursue the same harsh policies, thus intensifying the revolutionaries' hatred of the government. ${ }^{4}$

2 Dearborn, Queen of Bohemia, 23-38; Gardner, "Friend and Lover," 25-44.

3 Dearborn, Queen of Bohemia, 74-88; Gardner, "Friend and Lover," 62-125.

4 Sheila Fitzpatrick, The Russian Revolution, 1917-1932 (Oxford: Oxford University Press, 1982), 10-26; Orlando Figes, A People's Tragedy: The Russian Revolution, 1891-1924 (New York: Penguin Books, 1998), 3-121; See also Philip Pomper, The Russian 
There were other stresses as well. Though Russia had abolished its centuriesold practice of serfdom in 1861, it was still an overwhelmingly agricultural nation with a large population of impoverished peasants and a small group of elites who held social and political power. By the last quarter of the nineteenth century, however, the industrial revolution had begun to make its presence felt, straining Russia's traditional social structure with the creation of new social groups. Industrialization arrived later and more gradually in Russia than it did in other parts of Europe, but the results were the same - the emergence of a working class and an industrial middle class, neither of which fit neatly into the current Russian social system. ${ }^{5}$

These threats, combined with the enormous challenges on the international scene, eventually led to the first revolution in Russia in the twentieth century, the revolution of 1905. In 1904, Russia and Japan went to war over territorial conflicts in Manchuria. It was a humiliating defeat for Russia and it was, in part, Russia's miserable performance in the Russo-Japanese War which led to the outbreak of revolution in January 1905. In that month, a strike broke out in St. Petersburg and tied up several factories employing thousands of workers, and on Sunday, January 22, two hundred thousand of those workers joined in a protest march to the Winter Palace. Though the demonstration was meant to be an innocent and peaceful appeal to Nicholas, with many of the workers carrying icons and pictures of the tsar, when the workers came within sight of Palace Square they found their way blocked by troops and police. When they refused to stop, they were fired upon. Over one hundred people were killed and several hundred injured in what henceforth became known as Bloody Sunday. Such violence perpetrated against an unarmed crowd only intensified public dissatisfaction with the state of affairs in St. Petersburg and Russia. In the following months, Nicholas tried to placate the public with promises of a consultative assembly, but his attempts were fruitless, and strikes and demonstrations continued throughout the spring, summer, and early fall. Finally, faced with an enormous general strike in October 1905, Nicholas issued a document called the October Manifesto which created a nationally elected consultative assembly called the Duma. Though the Duma appeared promising on paper, in reality it changed little. The Duma had limited powers, and ministers remained solely responsible to the autocrat. After the first two Dumas were deemed insubordinate and arbitrarily dissolved, a new electoral system that virtually disfranchised some groups and heavily overrepresented the landed nobility was introduced. Thus, politically, the creation of the Duma failed to address Russia's problems. Yet another thing that the revolution of 1905 failed to put an end to was revolutionary attacks. In 1908, for example, 1800 officials were killed and 2083 were wounded in politically motivated attacks. While Nicholas's “com-

Revolutionary Intelligentsia (Arlington Heights, IL: Harlan Davidson, Inc., 1970); Richard Pipes, The Russian Revolution (New York: Vintage, 1991), 121-52.

5 Figes, A People's Tragedy, 46-48, 5-54; Pipes, The Russian Revolution, 91-120. 
promise" may have satisfied some moderates, for others it was too little, too late, and only fanned the flames of their revolutionary fervor. ${ }^{6}$

All of these problems were brewing at the surface when war broke out in August 1914. Most Russians greeted the war with patriotism and enthusiasm. Soon, however, the tide turned as Russia began to suffer defeat after defeat at the hands of the Germans. It was at this point that Nicholas made a fateful decision. In September 1915, the tsar dismissed his commander in chief and took command of the troops himself, leaving his wife, Alexandra, in the capital. The tsaritsa was a German princess by birth and largely reviled by the Russian public for her cold and haughty appearance. By 1915, there were already rumors of treason in the palace. Matters were only made worse by Alexandra's (and Nicholas's) strange fascination with and reliance on Grigory Rasputin who insinuated himself into the royal family through his seeming ability to stop the bleeding and pain of the hemophiliac heir to the throne, Alexis. Rasputin held great power at court, serving as a spiritual advisor to the royal family but also influencing political decisions and political appointments. Though Rasputin was murdered in 1916, the royal family's association with him weakened public perception of the monarchy. ${ }^{7}$

All of these problems together resulted in the collapse of the monarchy in early 1917. In late February (according to the Julian calendar, which was still in use in Russia at the time), while Nicholas was still at staff headquarters, riots and demonstrations broke out in Petrograd. These demonstrations, spontaneous and unexpected, consisted of factory workers on strike and housewives angry about food shortages. The government attempted to disperse the demonstrators by sending in reserve battalions, but the soldiers began to fraternize with the demonstrators instead, and there were no other troops in the city. With Nicholas at the front, authority largely collapsed and many officials went into hiding. The population of Petrograd then turned to the Duma for leadership. Recognizing the potential danger in this situation, the tsar tried to dissolve the Duma, but its members ignored his order, and on February 27, 1917, they created a Provisional Government. Meanwhile, another important group was also being formed: the Petrograd Soviet, a group of soldiers and workers with an ill-defined, yet evolving, political agenda. As these events were occurring, Nicholas attempted to return to Petrograd, but he was stranded by railroad strikes in the city of Pskov. There, faced with the realities already described, and aware that he no longer had the support of his army commanders, Nicholas abdicated both for himself and for his son, in favor of his brother Michael. When Michael failed to accept the throne with any decisiveness, the Romanov dynasty, which had lasted over three hundred years, from 1613 to 1917 , came to an end. ${ }^{8}$

${ }^{6}$ Fitzpatrick, The Russian Revolution, 1917-1932,26-32; Figes, A People's Tragedy, 173-96; Pipes, The Russian Revolution, 3-51.

7 Fitzpatrick, The Russian Revolution, 1917-1932, 32-33; Figes, A People's Tragedy, 246-78; Pipes, The Russian Revolution, 195-232.

8 Fitzpatrick, The Russian Revolution, 1917-1932,34-60; Figes, A People's Tragedy, 310-351; Pipes, The Russian Revolution, 272-337. 
The situation which followed was a strange one, consisting of dual power between two newly formed bodies, the Provisional Government and the Petrograd Soviet. The Provisional Government consisted mostly of Duma members and other officials from the more liberal and moderate parties. Since it had ignored the tsar's order to disband the Duma, the Provisional Government technically had no legitimate authority. It was thus supposed to be a temporary body in office until a Constituent Assembly could be elected, and because of its temporary nature, it put off dealing with critical questions, the most important of these being land reform and the war. The Provisional Government also recognized that it lacked the large popular support of its chief rival, the Petrograd Soviet, which had effective control over the capital. The leaders of the Soviet were mostly Socialist Revolutionaries and Mensheviks, two very different groups of socialists, and consisted primarily of workers and soldiers. Its authority came from the fact that hundreds of these soviets had developed throughout the country, and it was more or less the leading group. Its weakness lay in the fact that it was an unwieldy body of three thousand delegates and that its leaders were not in agreement about what should happen next. Many of the leaders of the Petrograd Soviet believed that the rule of the Provisional Government was a necessary stage according to Karl Marx's theory of a two-stage revolution. In their view, because tsarist Russia was still largely an agrarian society and industrialization had just begun at the end of the nineteenth century, both the bourgeoisie (middle class) and the working class were young and small. Consequently, these faithful Marxists believed that the revolution in February 1917 had ushered in an era of bourgeois rule, and therefore, they had to wait a period of time before overthrowing this bourgeois government. How long they had to wait was debated. For this reason then, the Petrograd Soviet tolerated the existence of the Provisional Government as it decided upon the proper moment to act. ${ }^{9}$

On the other hand, there was Vladimir Lenin, the Marxist theorist and revolutionary who was eager to establish a workers' state. Lenin had already gathered a faction of followers around him under the name of the Bolsheviks. When the Revolution broke out in February, Lenin was in exile in Switzerland. Writing from Switzerland, Lenin made it clear that he opposed the Provisional Government and hoped to topple it; he also expressed his intent and desire to take Russia out of the war. This last declaration of Lenin's meant that France and Italy, both allies of Russia, would not allow him passage to Russia. Germany, however, was more than happy to help Lenin get home; the only condition was that he travel in a sealed train car so that he could not incite any workers' movements in Germany along the way. So Lenin, along with his wife and several close associates, arrived in Petrograd in early April and began to try and persuade the other Bolsheviks in the Petrograd Soviet that it was time to stage the revolution. He explained his program for action in a document known as the "April Theses"; in it he presented his alternative to the two-stage revolutionary pattern of classical Marxism. Lenin broke with the traditional view that a period of bourgeois rule was necessary and

9 Fitzpatrick, The Russian Revolution, 1917-1932,34-60; Figes, A People's Tragedy, 354-61;Pipes, The Russian Revolution, 385-438. 
instead insisted that Russia could immediately go to the second stage of revolution. Thus he urged the Petrograd Soviet, as the representative of the working class, to take power immediately. Once in charge, Lenin promised to accomplish three things: to take Russia out of the war, to distribute land to the peasantry, and to give workers control over the factories. It was, of course, these things which the Provisional Government refused to do, and this would ultimately result in its downfall. ${ }^{10}$

Throughout the summer of 1917, the Provisional Government continued to pursue the same unsatisfactory policies. In late June and early July, it launched the last Russian offensive of World War I, an attack on Austro-German forces along a broad front in Galicia, which ultimately failed. This misstep resulted in more riots and a failed attempt by the Bolsheviks to overthrow the Provisional Government. When the rebellion was put down, Lenin fled to Finland and some other Bolsheviks, including Trotsky, were arrested. Following this political and military disaster, the prime minister of the Provisional Government, Prince Georgy Lvov, resigned and Alexander Kerensky took his place. During the same period, the All-Russian Congress of Soviets emerged as the body that would represent the hundreds of smaller soviets across the country, with delegates of various political leanings, including Socialist Revolutionaries, Mensheviks, and Bolsheviks. ${ }^{11}$

In the next months the Provisional Government faced challenges it simply could not overcome. In early September there was an attempt to overthrow the government by a Russian military commander, Lavr Kornilov. In an effort to save the government, Kerensky appealed to the Petrograd Soviet for help, releasing a number of Bolshevik leaders from prison and then arming the workers' militia known as the Red Guard. This tactic worked and the coup was stopped, but the Provisional Government paid the price nonetheless. It came out of the crisis looking weaker than before, while the position of the Bolsheviks was greatly strengthened. In fact, it was their leadership in putting down the attempted coup which gave them the strength and popularity to finally win control of both the Petrograd and Moscow Soviets. ${ }^{12}$

Finally, in October the Bolsheviks took action. In early October Lenin returned to Petrograd and began to convince the other leading Bolsheviks of his plan. It was finally decided that the insurrection was to take place in late October under the cover of the coming Congress of Soviets. Up until the last minute, however, there were many dissenters within the Soviet leadership. The Great October Socialist Revolution, as it came to be known in Soviet mythology, was in reality a small-scale event, a military coup that passed unnoticed by the majority of residents in Petrograd. The popular image of the Bolshevik Revolution as a bloody struggle by tens of thousands, with thousands of fallen heroes, is completely fab-

${ }^{10}$ Fitzpatrick, The Russian Revolution, 1917-1932,34-60; Figes, A People's Tragedy, 384-87; Pipes, The Russian Revolution, 341-84.

${ }^{11}$ Fitzpatrick, The Russian Revolution, 1917-1932,34-60; Figes, A People's Tragedy, 279-82, 421-438; Pipes, The Russian Revolution, 385-438.

${ }^{12}$ Fitzpatrick, The Russian Revolution, 1917-1932,34-60; Figes, A People's Tragedy, 451-61; Pipes, The Russian Revolution, 385-438. 
ricated. On the night of October 24-25, the coup was carried out under Trotsky's leadership, as the Red Guard seized the vital centers in Petrograd, including the telephone exchange and the electricity and railroad offices. The Provisional Government held out briefly in the Winter Palace, but their defenses were weak; the majority of the soldiers in Petrograd supported the Bolshevik takeover. ${ }^{13}$

Over the next nine months, Lenin and the Bolsheviks worked to consolidate their control and began to shape Russian life. Immediately after the coup, Lenin set out to establish a new government, naming himself as prime minister and Trotsky as commissar of foreign affairs. The first challenge Lenin faced was to tackle the problems which had brought down the monarchy and the Provisional Government. So, the new government approved the seizing of land by peasants, which had already been taking place, and put factories in the hands of workers' committees. It also issued a Decree on Peace which called for an immediate end to the war with Germany and for a peace settlement without annexations or reparations. In late November, an armistice between Russia and Germany was declared and peace negotiations began in the city of Brest-Litovsk, the site of German military headquarters. Trotsky, as Russia's representative, tried to hold his ground, but Germany demanded large areas of land. When Trotsky continued to refuse, the Germans launched an offensive that soon came dangerously close to Petrograd. Lenin then persuaded his new government to accept the harsh terms; he intended to evade the terms as much as possible, and he did not want to lose the gains of the revolution by provoking a German invasion. He ultimately thought Germany would soon be defeated, and a workers' revolution would emerge there as well. Thus in March 1918, the Treaty of Brest-Litovsk was signed. As a result of the treaty, Russia lost some 1.3 million square miles of land, including Finland, Estonia, Latvia, and Lithuania, most of Poland, and Bessarabia. Russia also agreed to recognize Ukrainian independence. ${ }^{14}$

Even this harsh treaty was only a minor setback for Lenin; over the next months, he continued to consolidate his power with increasingly radical measures. In March 1918, he renamed the Bolshevik Party the Communist Party, and in May he began a program of forced grain requisitions in order to get food for the cities. That summer, in July 1918, a new constitution was adopted by which supreme power was placed in an All-Russian Congress of Soviets. Among other things, the constitution restricted civil rights and the right to bear arms to members of the working class. Even as Lenin worked to stabilize his new regime, however, opposition forces rebelled and began a civil war that would last three years. It was during this early period of the Civil War that Lenin and his new government decided to eliminate the largest remaining threat to their power, the existence of the royal family. Since April 1918, Nicholas II and his family had been sequestered in Ekaterinburg, a city located near the Ural Mountains, where they were kept as prisoners, locked away in a small house with painted-over windows. In early July,

${ }^{13}$ Figes, A People's Tragedy, 469-500; Pipes, The Russian Revolution, 439-505.

${ }^{14}$ Fitzpatrick, The Russian Revolution, 1917-1932, 34-60; Figes, A People's Tragedy, 500-51; Pipes, The Russian Revolution, 567-605. See also John W. Wheeler-Bennett, Brest-Litovsk: The Forgotten Peace, March 1918 (New York: W. W. Norton, 1971). 
with the permission of Moscow party officials, the entire family was awakened in the middle of the night and told that they were being moved to a safer location. Once they were assembled in the basement, armed guards entered the room and executed the entire family, along with their pets and several servants, with gunfire and bayonets. The first stage of the revolution was complete. ${ }^{15}$

Bryant's story does not end with the success of the Bolshevik Revolution and the beginning of totalitarian rule in Russia and, ultimately, the Soviet Union. She returned to the United States in February 1918 and immediately began working on the book that would become Six Red Months in Russia. Reed would return two months later. Working with impressive speed, Bryant published her book in October of the same year, and in early 1919, began giving talks on Russia, discussing her book and expressing her opposition to Allied intervention. By this time, of course, the Paris Peace Conference was underway, and politicians and leaders in all of the Allied countries were fearful of the spread of Bolshevism into Europe during this period of postwar instability. In the United States, this fear sparked the creation of a committee under the leadership of North Carolina Senator Lee S. Overman to investigate Bolshevism and other forms of anti-American radicalism. Eventually, Bryant would be called to testify before the committee in February 1919. Before being called on the carpet for her Bolshevik sympathies, however, Bryant found herself in trouble for her involvement in a suffragist march on the White House. She was among the forty or so women arrested and spent several days in jail, engaging in a hunger strike with the others to draw greater attention to their cause. ${ }^{16}$

Through 1919, Bryant and Reed continued to believe in the inevitability of a world revolution, despite a failed communist coup d'etat in both Hungary and Germany. Bryant continued to travel around the country giving speeches, but was dismayed by the continued fear of communism in the United States. She was deeply disturbed by the anti-communist Palmer raids of 1920, in particular. Carried out by the Justice Department's Bureau of Investigation headed by J. Edgar Hoover, the raids included document confiscations at the offices of the American Communist Party and the Communist Labor Party in New York. During this period, Bryant continued to write, covering the trial of one of her socialist acquaintances who had been rounded up in the Palmer Raids. ${ }^{17}$

In the summer of 1920, Bryant headed to Russia yet again, intending to meet up with Reed, who was already there. During her stay in Russia, Bryant interviewed Lenin and published the interview in the Washington Times in midOctober. Only three days later, Bryant was dealt one of the harshest blows of her life when Reed died of typhus in a Moscow hospital Though devastated, Bryant remained in Moscow filing cables almost daily with the International News Service and serving as one of the few reliable sources on Russia for the American

${ }^{15}$ Fitzpatrick, The Russian Revolution, 1917-1932, 61-84; Figes, A People's Tragedy, 556-642; Pipes, The Russian Revolution, 506-65, 671-788.

${ }^{16}$ Dearborn, Queen of Bohemia, 117-35; Gardner, "Friend and Lover," 146-53.

17 Dearborn, Queen of Bohemia, 136-52; Gardner, "Friend and Lover," 171-93. 
press. In 1923, her second book on Russia, Mirrors of Moscow, was published. Written in a more sober tone, it was a collection of portraits of Russian leaders and other people she had interviewed, including Lenin, Trotsky, Kollontai, and Felix Dzerzhinsky, the head of the Russian secret police, the Cheka. The book received favorable reviews, demonstrating once again Bryant's skills as a journalist, now free from the shadow of her lover and competitor, John Reed. ${ }^{18}$

The year 1923 was a turning point in Bryant's life for two other reasons; it was the year she began to suffer from recurring bouts of illness and the year that she married the wealthy diplomat William Bullitt. The illness, which would plague her for the rest of her life with depression, irritability, lethargy, and weight gain, would be diagnosed in 1928 as the rare disorder Dercum's disease. It would not only contribute to the decline of her once-admired beauty, but it also undoubtedly played a role in her increasing consumption of alcohol in the later years of her life. The marriage would end in divorce in 1930, and in estrangement from her child, who lived with Bullitt. Bryant died in France in 1936. ${ }^{19}$

Though much of Bryant's talent was overshadowed by her sex and her relationship with Reed, she was, in fact, a remarkable woman for her time. Writer, suffragist, socialist, worldly and adventurous journalist, dissenter from social norms - all of these labels can be applied to Bryant, yet none of them alone fully identifies her accomplishments. Bryant moved throughout sophisticated circles during her life, befriending many of the luminaries of the early twentieth century, men like Eugene O'Neil, Ernest Hemingway, Clarence Darrow, Claude McKay, and Ford Maddox Ford. She interviewed not only Russian leaders but also the Italian Fascist dictator Benito Mussolini and the leader of the 1908 Young Turk Revolution Enver Pasha. Unfortunately, her contemporaries - male and femaleoften dismissed her as just a pretty face or the attractive appendage of an important man. Her book Six Red Months in Russia has long been eclipsed by Reed's Ten Days That Shook the World, and even the well-known Warren Beatty film Reds portrays Bryant, played by Diane Keaton, as more of a dependent than a freestanding character, with little identity separate from Reed's. ${ }^{20}$

Bryant did, in fact, have her own voice and was a skilled observer and journalist in her own right. While Reed's book is certainly an important work, documenting the revolution as a major historical event, it contains little personal commentary on the events he witnessed. Bryant's account, on the other hand, is also a documentation of the revolution, but it goes further than Reed's in many ways, incorporating interpretation and observation. Bryant communicates to readers what life was like during the days of the revolution - the people, the food, the excitement, the fear. She is keenly aware of her American audience and speaks directly to them, urging them to pay attention to this world-changing moment in history and not to be fooled by the rumors and misinformation about the nature of Bolshevism and the new regime. Six Red Months in Russia conveys Bryant's confidence in her own writing and in her understanding of the revolution and

${ }^{18}$ Dearborn, Queen of Bohemia, 153-87; Gardner, "Friend and Lover," 194-236.

${ }^{19}$ Dearborn, Queen of Bohemia, 191-301; Gardner, "Friend and Lover," 239-95.

${ }^{20}$ Dearborn, Queen of Bohemia, 5, 172-74, 208-11, 234-35, 304-09. 
reminds us of the utter enthusiasm that many Russians, and Americans, felt for socialism and its yet-untainted, utopian ideals. ${ }^{21}$

Now, at the centennial of the Russian Revolution, it is important for us to reconsider accounts such as Bryant's. The spectacular events of 1917 have played themselves out and students of Russia can analyze and examine the revolution and its aftermath with the perspective and the benefit of a long historical lens. It is an opportunity to consider the role of the observer in historical events and, in particular, when those events occur in a country that is not one's own. Is the outside observer able to see with greater clarity? Or does one need to be deeply rooted in a country's history and culture to truly understand monumental changes like revolution? The works of Bryant and others may not answer these questions, but in a world of growing political, cultural, economic, and social interconnectedness, the questions are worth asking.

There is another reason to re-examine the Russian Revolution and our (America's) reaction to it. Russia and the United States have a long and complicated history together. After establishing official diplomatic relations early in the nineteenth century, they remained on more or less good terms until 1917. The Russian Revolution was a turning point as it changed the way in which the two nations interacted for some seventy years. Communism in Russia has come and gone; the Cold War is over. Nonetheless, though Russia and the United States are no longer mortal enemies, their relationship is always complex and uneasy. Understanding the history of that relationship is key to navigating the choppy waters of RussianAmerican diplomacy in the future.

${ }^{21}$ Dearborn, Queen of Bohemia, 85-88, 93-96. 